University of Nebraska - Lincoln

DigitalCommons@University of Nebraska - Lincoln

Publications from USDA-ARS / UNL Faculty

U.S. Department of Agriculture: Agricultural

Research Service, Lincoln, Nebraska

2008

\title{
Agronomy Journal Turns One Hundred
}

\author{
Calvin H. Pearson \\ Colorado State University - Fort Collins, calvin.pearson@colostate.edu
}

Susan M. Ernst

Ken A. Barbarick

Colorado State University - Fort Collins

Jerry L. Hatfield

USDA-ARS, jerry.hatfield@ars.usda.gov

Gary A. Peterson

Colorado State University - Fort Collins, gary.peterson@colostate.edu

See next page for additional authors

Follow this and additional works at: https://digitalcommons.unl.edu/usdaarsfacpub

Pearson, Calvin H.; Ernst, Susan M.; Barbarick, Ken A.; Hatfield, Jerry L.; Peterson, Gary A.; and Buxton, Dwayne R., "Agronomy Journal Turns One Hundred" (2008). Publications from USDA-ARS / UNL Faculty. 1346.

https://digitalcommons.unl.edu/usdaarsfacpub/1346

This Article is brought to you for free and open access by the U.S. Department of Agriculture: Agricultural Research Service, Lincoln, Nebraska at DigitalCommons@University of Nebraska - Lincoln. It has been accepted for inclusion in Publications from USDA-ARS / UNL Faculty by an authorized administrator of DigitalCommons@University of Nebraska - Lincoln. 


\section{Authors}

Calvin H. Pearson, Susan M. Ernst, Ken A. Barbarick, Jerry L. Hatfield, Gary A. Peterson, and Dwayne R. Buxton 


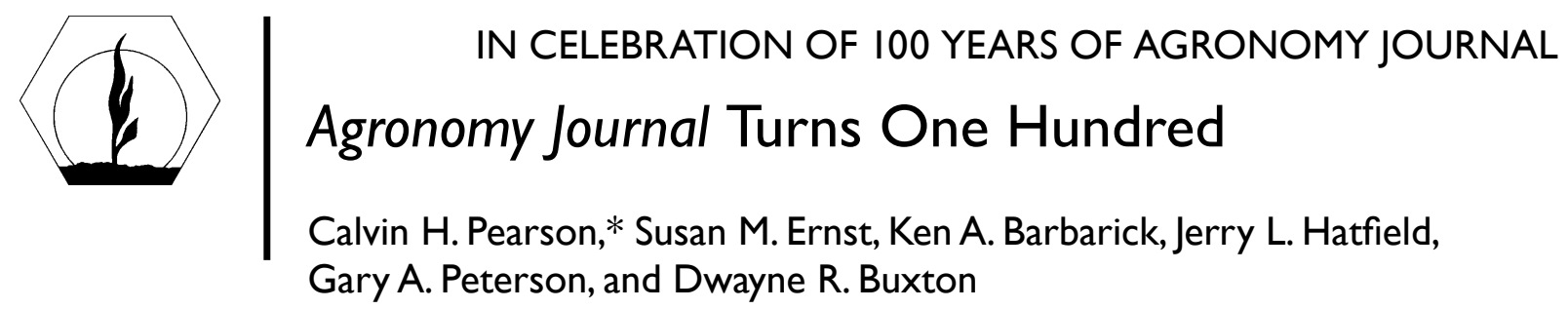

\begin{abstract}
During 2008 we celebrate the centennial anniversary of Agronomy Journal. Many people have certainly been influenced in some way by the science published during the 100-yr existence of the journal. From Volume 1 up through Volume 98 (2006) there have been more than 30,290 authors who published 15,232 articles totaling 89,056 pages. More than 2545 editors were required to review and edit the papers published in Agronomy Journal, in addition to the manuscripts submitted but not published. As a current snapshot of Agronomy Journal, we published 60\% of the manuscripts submitted in 2005. In both 2003 and 2004 , we accepted 55\% of the manuscripts submitted. In a comparison of 48 peer journals in 2005, the impact factor of Agronomy journal ranked 12th at 1.473 and the total citations for the journal ranked fourth at 6723 . Commentaries on the early history of Agronomy Journal have been previously published. In our article, we focus on the journal's history during the past 25 yr. We fully expect that the future of Agronomy Journal will be even more exciting, rewarding, challenging, and valued as the past $100 \mathrm{yr}$. We eagerly look forward to the next $100 \mathrm{yr}$ of Agronomy Journal.
\end{abstract}

$\mathrm{D}$ URING 2008 WE WILL PUBLISH VOLUME IOO of Agronomy Journal-marking the centennial anniversary of the journal. Also, this first issue of 2008 debuts a redesign of the journal. The publishing industry is undergoing rapid and substantial changes, much of which is to our advantage. This gave us an opportunity to redesign Agronomy Journal at a low cost and we chose to schedule it as part of the centennial anniversary.

The Volume 100 redesign included consideration of the following: journal cover redesign (layout and format orientation, color choices and combinations, fonts and sizes), article title page layout, updated font combinations and sizes, ragged right versus full justification, two-color, two versus three columns, footers, headers, page number placement, sidebars, pull quotes, increased use of photographs, shading, and shadows.

The first four volumes (1908-1912) of Agronomy Journal were titled the Proceedings of the American Society of Agronomy and Volumes 5 through 40 (1913 through 1948) were titled the Journal of the American Society of Agronomy. Following a vote by the membership, the name was changed to Agronomy Journal in January 1949. At the same time, the format was changed from 6 by 9 inches to a trimmed size of 8.5 by 11 inches (ASA, 1948b). Agronomy Journal has retained its current name since 1949 .

C.H. Pearson, K.A. Barbarick, and G.A. Peterson, Colorado State University, Fort Collins, CO 80523; S.M. Ernst, 677 S. Segoe Rd., Madison, WI 53711; J.L. Hatfield, USDA-ARS National Soil Tilth Laboratory, 2150 Pammel Dr., Ames, IA 50011; D.R. Buxton, USDAARS, 800 Buchanan Street, Albany, CA 94710. Received 8 Nov. 2006. ${ }^{*}$ Corresponding author (calvin.pearson@colostate.edu).

Published in Agron. J. 100:1-8 (2008).

doi:10.2134/agronj2006.0312c

Copyright (C) 2008 by the American Society of Agronomy, 677 South Segoe Road, Madison, WI 53711. All rights reserved. No part of this periodical may be reproduced or transmitted in any form or by any means, electronic or mechanical, including photocopying, recording, or any information storage and retrieval system, without permission in writing from the publisher.
During the 100 yr of Agronomy Journal, there have been ongoing changes to the journal, including six major design changes. These previous design changes first appeared in Volume 5 (1912), Volume 39 (1947), Volume 41 (1949), Volume 75 (1983), Volume 91 (1999), and Volume 100 (2008).

With the journal reaching such a significant milestone we are presented with a unique opportunity to celebrate, reflect, and anticipate the future. Many people, both in and out of agriculture, too numerous and too varied to mention, have been influenced in some way by the science contained in the 100 volumes of Agronomy Journal.

In pondering $100 \mathrm{yr}$ of Agronomy Journal, various questions come to mind. While these questions may have no definitive answers they are nonetheless questions worthy of reflection. Our intent with these questions is to encourage the reader to contemplate the contributions, challenges, and value of this publication during the past $100 \mathrm{yr}$ and on into the future. The questions are not presented in any particular order and many more questions could be added to this short list.

- What papers, published in Agronomy Journal, have had the greatest positive impact on society?

- How has the way we conduct agronomic research changed during the last $100 \mathrm{yr}$ ?

- How have the topics published in Agronomy Journal changed in the past $100 \mathrm{yr}$ ?

- Have we met important needs of society through the research findings published in the journal during the past $100 \mathrm{yr}$ ?

- Is Agronomy Journal well positioned to meet the needs of our society and our profession for the future?

\section{HISTORICAL DATA FOR AGRONOMY JOURNAL}

From Volume 1 up through Volume 98 (2006) there have been more than 30,290 authors who published 15,232 articles, totaling 89,056 pages (Fig. 1). More than 2545 editors (the number of editors was counted by adding the number 


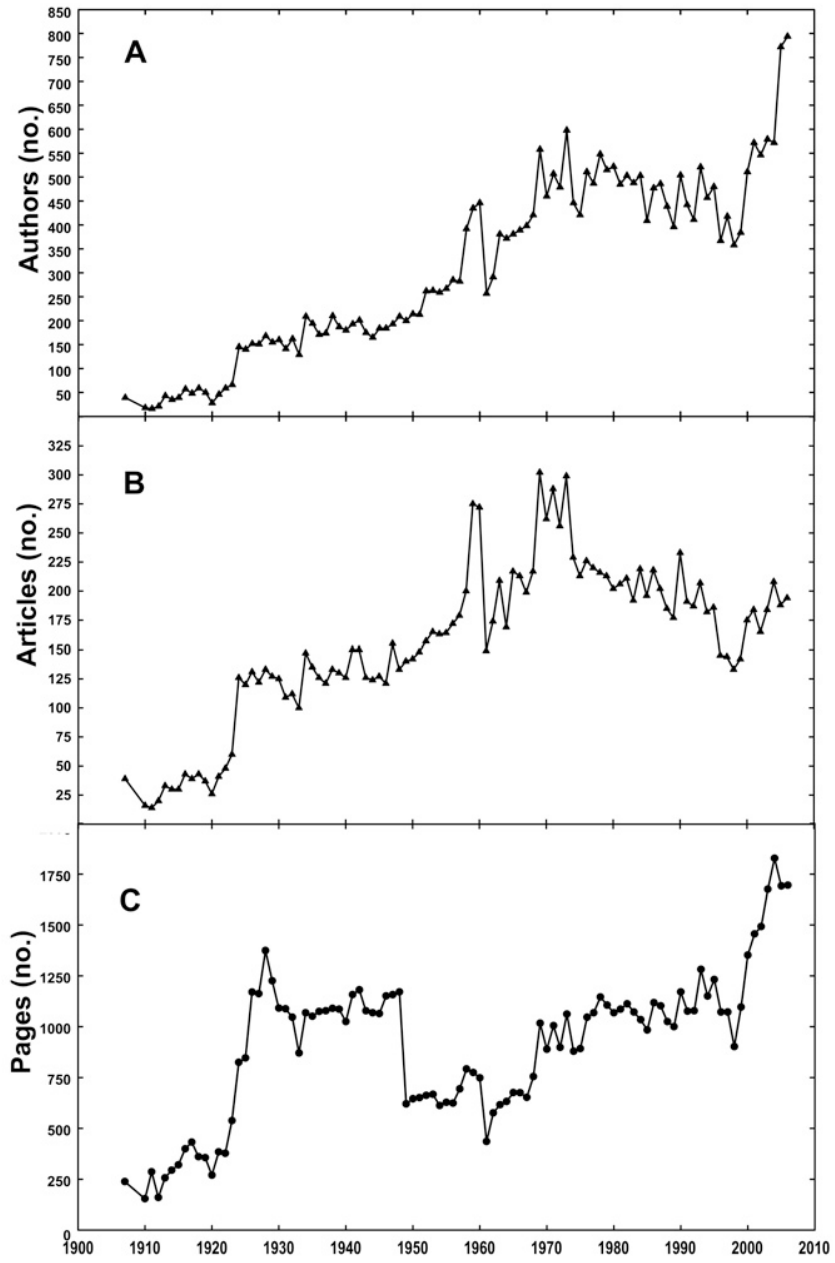

Fig. I. Numbers of (A) authors, (B) articles, and (C) pages included in each volume of Agronomy Journal from 1908 to 2006. The same author may have been counted more than once if the author had more than one paper in a given year.

of people serving on the Editorial Board for each year) were needed to review and edit the papers published in Agronomy Journal (Fig. 2), in addition to the manuscripts submitted but not published.

The following facts about Agronomy Journal may interest the reader.

- The largest volume of Agronomy Journal was published in 2004 (Fig. 1C). Volume 96 contains 1828 pages and consists of 208 articles.

- The single largest issue of Agronomy Journal published from the period 1908-2006 was the May-June 2006 issue. This issue is a hefty 456 pages ( 460 pages with front matter).

- Volume 61 (1969) contains the most articles at 302 (Fig. 1B) and has 1017 pages. Volume 65 (1973) has the second most articles at 299 and total pages are 1062.

- The most authors in a single year (794) was in 2006 (Vol. 98) (Fig. 1A). If someone authored more than one paper, they were counted each time they were listed as an author on an article.

- For years where data are available, the largest number of reviewers needed to publish a volume of Agronomy Journal was 654, which was Vol. 92 (2000) (Fig. 3). The number of reviewers needed to review papers sub-

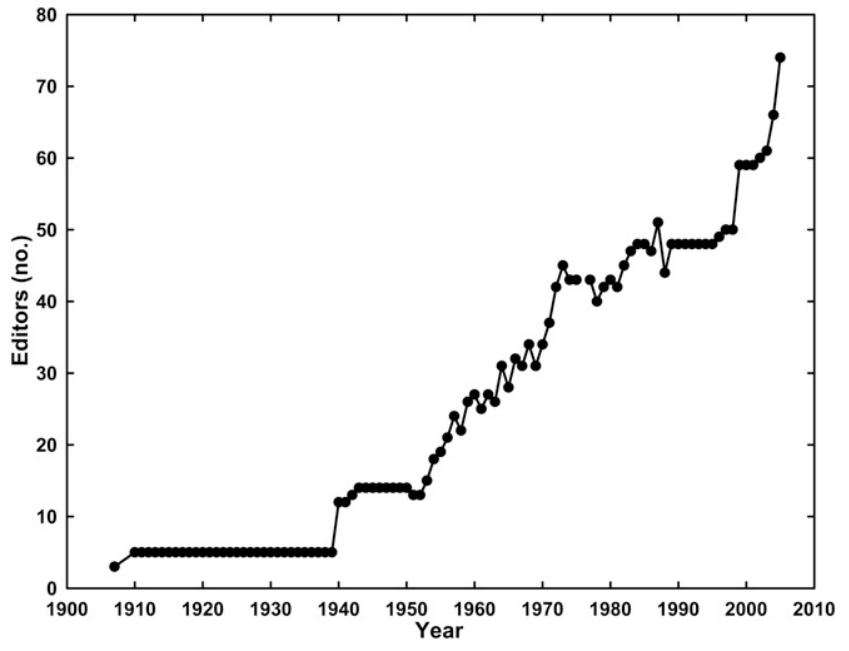

Fig. 2. The number of members on the Editorial Board of Agronomy Journal each year from 1908 to 2006.

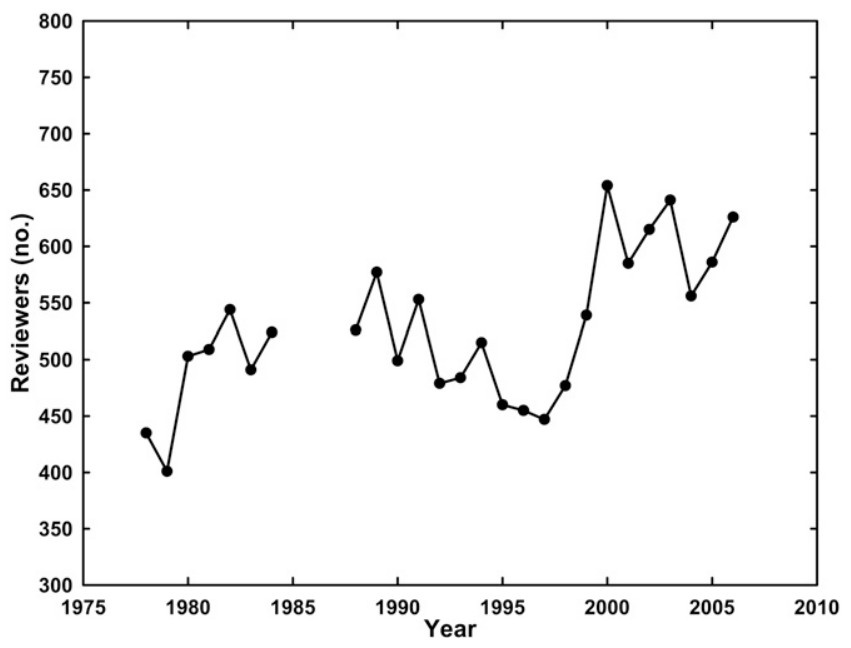

Fig. 3. Number of reviewers who peer reviewed manuscripts each year for the Agronomy Journal Editorial Board from 1978 through 1984 and from 1988 through 2006.

mitted to the journal has come close to or exceeded 600 in many recent years.

- The number of ASA members who subscribed to Agronomy Journal peaked in 1985 at 7742 while the number of nonmembers (e.g., libraries, companies, organizations, individuals) peaked in 1976 at 2151 (Fig. 4). The number of members who subscribe to Agronomy Journal has decreased every year from 1985 through 2005, and for nonmembers this decrease has also continued nearly every year since peaking in 1976. In 2006, the total number of subscriptions was down from 2005 by 205 due to a drop in nonmember subscriptions; however, after experiencing decreases for $20 \mathrm{yr}$, member subscriptions increased by 434 in 2006. Such a sustained decline in both member and nonmember subscribers to Agronomy Journal has created ongoing concern over the long-term health of this publication.

During the $100 \mathrm{yr}$ of Agronomy Journal there have been 14 Editors (Fig. 5). Their affiliations and service periods are presented in Table 1. Both J.D. Luckett and Matthias Stelly each served as Editor for $21 \mathrm{yr}$. Dr. Buxton was appointed 
as both Editor and Editor-in-Chief of the American Society of Agronomy. After 2 yr, the Executive Board of the Society, with concurrence from Dr. Buxton, decided to separate the two positions.

In the early years of Agronomy Journal, only three to five people comprised the Editorial Board. In recent years, the number of people serving on the Editorial Board has reached nearly 75 (Fig. 2).

\section{CHANGES IN AGRONOMY JOURNAL IN RECENT YEARS}

Commentaries that include historical information about Agronomy Journal have been previously published (Lyon, 1933; Throckmorton, 1941; Laude et al., 1962; Smith, 1980; ASA, 1983b; Fuccillo, 1983). Lyon (1933) provided an early history of the journal, dating from its beginning up to 1930 . The Diamond Jubilee of the American Society of Agronomy was celebrated in 1982 and Volume 75 was published in 1983. The historical highlights published in Agronomy Journal (ASA, 1983b) focuses mainly on the society but also contain some historical information related directly to the journal. Laude et al. (1962) and Fuccillo (1983) have provided detailed histories of the first $75 \mathrm{yr}$ of Agronomy Journal. These articles are invaluable to those who are interested in the evolution of Agronomy Journal. The major objective of our article is to document the journal's history during the past $25 \mathrm{yr}$.

\section{| $982-1983$}

Dwayne R. Buxton, currently the oldest living former Editor of Agronomy Journal, served in this position for $2 \mathrm{yr}$ while at the same time serving as Editor-in-Chief of ASA. It was during his tenure that the two positions were separated (ASA, 1983a). During Dr. Buxton's relatively short time as Editor several significant changes occurred. The Editor's position was moved from a paid position at Headquarters

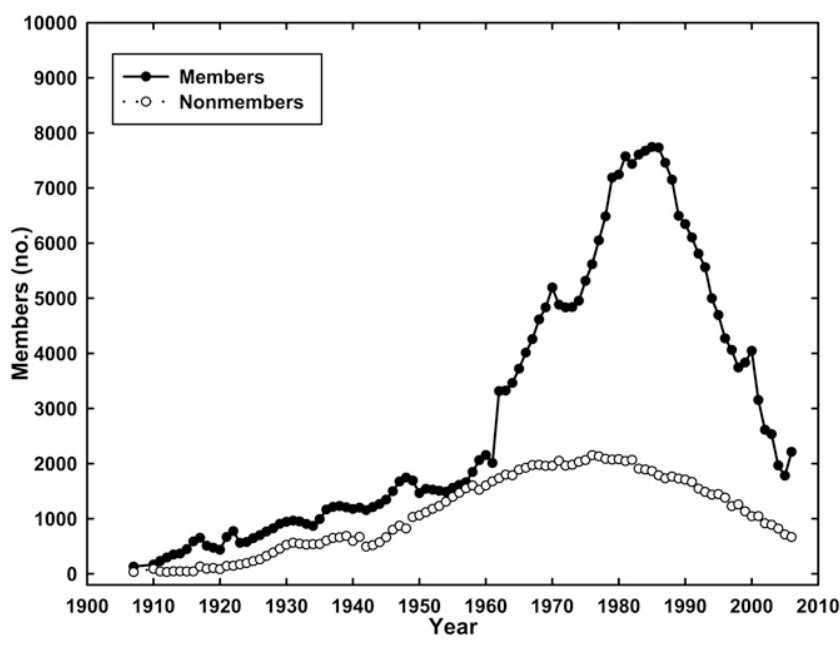

Fig. 4. The numbers of members and nonmembers who subscribed to Agronomy Journal from 1908 to 2006.

to a nonpaid scientist working at a location away from Headquarters. This occurred in 1983, when his two appointments were separated (ASA, 1984a). Subsequently, Dr. Gary A. Peterson was appointed as Editor of the journal and Dr. Buxton continued to serve as Editor-in-Chief for four more years.

The SI system (Système International d'Unités) of reporting units was introduced but not without encountering some resistance and controversy from peer scientists (ASA, 1982). The handbook of instructions for authors was revised in 1982 and subsequently published (ASA, 1983a, 1984b, 1985) along with a handbook to help editors (ASA, 1986, 1987) to be more effective in handling manuscripts and working with authors.

\section{4-1989}

Before 1984, all manuscript submissions were sent to Headquarters, which was appropriate when Dr. Stelly was

Table I. Editors, their affiliation, dates of service, and number of years of service during the 100 yr Agronomy Journal has been published.

\begin{tabular}{|c|c|c|c|}
\hline No. & Editor & Affiliation & Dates of service \\
\hline I & Carleton R. Ball & $\begin{array}{l}\text { Office of Cereal Crops and Diseases, Bureau of Plant } \\
\text { Industry, USDA, Washington, DC (Ball et al., 1928) }\end{array}$ & 1909-1914 (Throckmorton, 194I) \\
\hline 2 & C. W. Warburton & Director of Extension Work, USDA, Washington, DC (Warburton, 1925) & 1915-1921 (Throckmorton, 194I) \\
\hline 3 & R. W. Thatcher & $\begin{array}{l}\text { Director of Experiment Stations, Cornell University, Geneva, NY; Director of } \\
\text { the New York Agricultural Experiment Station (Fuccillo, 1983; Thatcher, 1927) }\end{array}$ & 1922-1927 (Throckmorton, 194I) \\
\hline 4 & J. D. Luckett & $\begin{array}{l}\text { Editor, New York State Agricultural Experiment } \\
\text { Station, Geneva, NY (Luckett, 1927) }\end{array}$ & $\begin{array}{l}\text { 1928-1948 (Throckmorton, } \\
\text { 1941; Fuccillo, 1983) }\end{array}$ \\
\hline 5 & Maurice R. Haag & $\begin{array}{l}\text { Assistant Extension Editor at Univ. of Wisconsin, Experiment Station } \\
\text { Editor at Univ. of Wyoming, and Managing Editor of the Proceedings } \\
\text { of the Soil Science Society of America (Fuccillo, 1983) }\end{array}$ & $\begin{array}{l}\text { Jan. 1949-1952 } \\
\text { (ASA, 1948a) }\end{array}$ \\
\hline 6 & W. Charles Robocker & Assistant in Agronomy at the University of Wisconsin (ASA, 1952) & July 1952-April 1953 \\
\hline 7 & L. G. Monthey & $\begin{array}{l}\text { Executive Secretary of ASA and Editor of What's } \\
\text { New in Crops and Soils (ASA, 1953) }\end{array}$ & Apr 1953-1961 \\
\hline 8 & Matthias Stelly & $\begin{array}{l}\text { Before becoming Editor he was at Louisiana State University, Agronomist at } \\
\text { the Soil Testing Lab; was Editor and ASA Executive Secretary (Fuccillo, 1983) }\end{array}$ & $\begin{array}{l}\text { Apr. 1961-1982 } \\
\text { (Smith, 1980; Fuccillo, 1983) }\end{array}$ \\
\hline 9 & Dwayne R. Buxton & Research Plant Physiologist, USDA-ARS, Ames, IA & $1982-1983$ \\
\hline 10 & Gary A. Peterson & Colorado State University, Dep. of Agronomy & $1984-1989$ \\
\hline II & Jerry L. Hatfield & USDA-ARS, National Soil Tilth Laboratory, Ames, IA & $1990-1995$ \\
\hline 12 & Kenneth A. Barbarick & Colorado State University, Dep. of Soil \& Crop Sciences & $1996-200 \mid$ \\
\hline 13 & Calvin H. Pearson & $\begin{array}{l}\text { Colorado State University, Dep. of Soil \& Crop } \\
\text { Sciences, Agricultural Experiment Station }\end{array}$ & $2002-2007$ \\
\hline 14 & Donald G. Bullock & University of Illinois, Dep. of Crop Sciences & 2008 to present \\
\hline
\end{tabular}




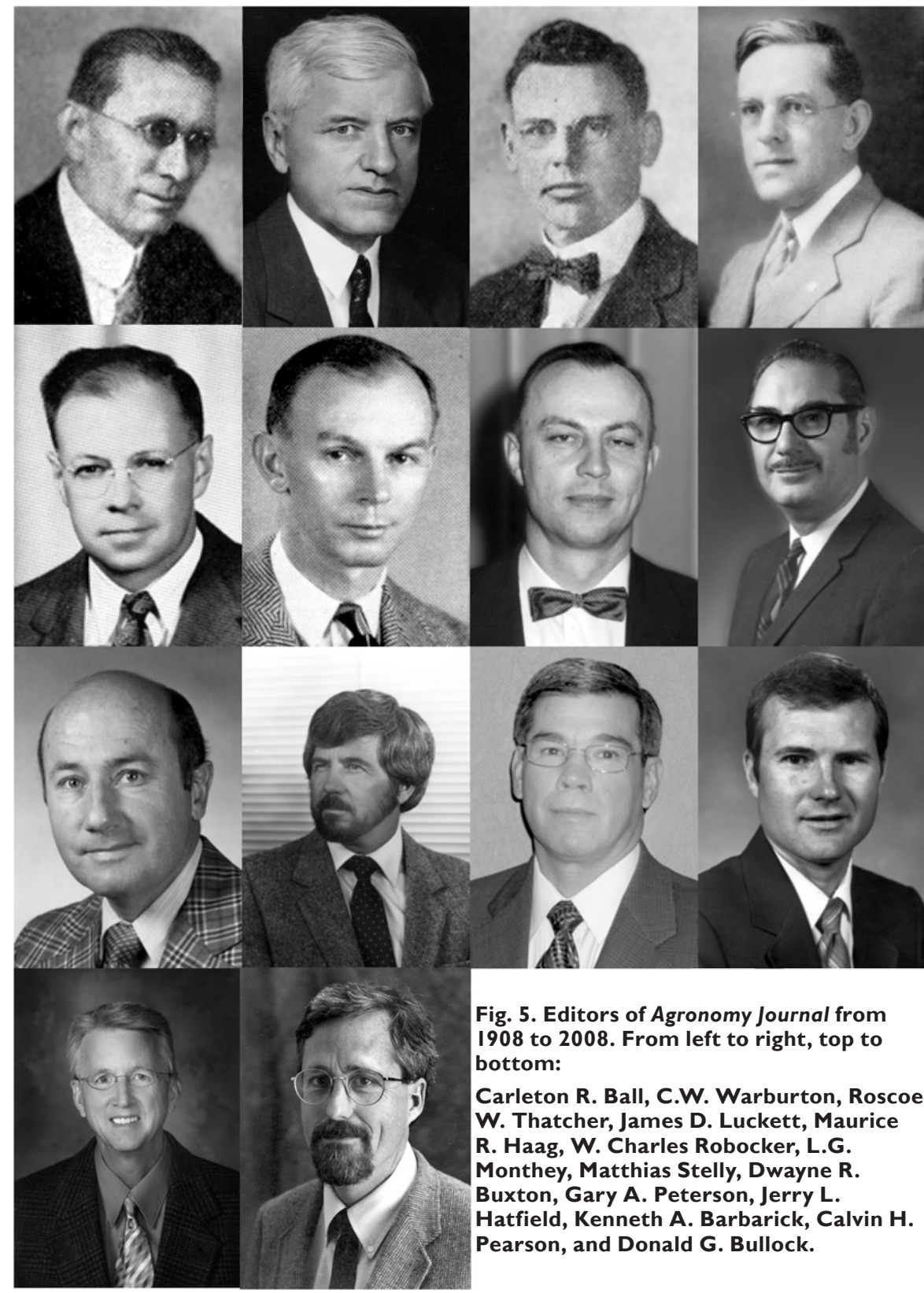

the Editor. However, that system created a problem for a volunteer Editor because he did not see manuscripts submitted to the journal, and only received copies of correspondence concerning the release of manuscripts to authors. Therefore, a new system was created in 1984, whereby manuscripts were submitted directly to the Editor and he assigned them to Technical Editors (ASA, 1985).

During this era of journal history, the Editorial Board was very concerned about the amount of time required for review and revision of manuscripts. In the 1984-1985 time period, the process took 7 to 9 mo for accepted manuscripts to move through the review process. An additional 4 to 5 mo were required before manuscripts were actually published, and thus, the total time from submission to publication averaged 11 to $14 \mathrm{mo}$. The Editorial Board focused their efforts on decreasing the amount of time between submission and the first communication back to the author because they believed that was the most crucial step. As a result, the time for this critical step averaged 9 to $10 \mathrm{wk}$, which was con- sidered quite good, given that there was considerable mailing time involved. The Editorial Board also observed that delays in getting a manuscript to publication were frequently the result of authors not responding promptly after receiving their reviews. At the Editorial Board meeting held in 1988 in Anaheim, CA, the Editorial Board adopted the 3-mo rule in which authors were allowed $90 \mathrm{~d}$ to complete a revision (ASA, 1989b). Shortening the time for authors to complete a revision from 6 to 3 mo was instituted to encourage authors to respond in a timely manner to editorial comments.

In response to a membership initiative, Agronomy Journal began to solicit review articles during this era. The Editor requested potential titles, subject matter areas, and authors from the membership, and 12 suggestions were received in the first round of solicitation. The invited review papers were subject to the standard review process. The goal was to publish two or three review papers during 1988 and at least two or three additional papers per year on into the future.

During this time period, Agronomy Journal developed a policy regarding the publication of models, and they were first published in a journal section called Agroclimatology and Agronomic Modeling. Software Scene, a place to publish new software, was also added and the first three of such papers appeared in the MarchApril issue of 1989.

After much discussion the Editorial Board agreed to divide the table of contents into categories to assist readers in finding papers specific to their interests. The initial five categories agreed on were: Crops, Soils, Agroclimatology and Modeling, Notes, and Software Scene. These categories first appeared in the January-February issue of 1990 (ASA, 1990). Later it was proposed that Agroclimatology and Modeling be split into two parts to help attract more modeling papers.

Interestingly, in fall 1987, the question was raised about the possibility of electronic manuscript submission. Guidelines already existed for submitting a manuscript on disk once it had been reviewed and approved for publication, but Managing Editor Bill Luellen reported that submission, review, and editing of papers online was still a few years down the road (ASA, 1988).

\section{0-1995}

Concern over the quality of the reviews and potential bias in the reviews because of name recognition of authors prompted a change in the review process. The journal reviewers, as a standard practice, were anonymous to authors, and comments were often received about the unprofessional 
nature of the comments. One of the roles of Associate Editors and Technical Editors was to remove any biased and unprofessional comments from reviewer comments. As an experiment, the review process changed to a completely double-blind review in which the author's names and institutions were removed from the manuscript (ASA, 1992). After $3 \mathrm{yr}$, a survey was conducted about the review process and it was determined that the double-blind review process imparted increased confidence about the quality of the reviews such that this procedure became standard operating procedure.

During the 1990s there was ongoing discussion about the appropriate statistical tools to be used in agronomic research. This affected statistical analyses used in research papers and finally culminated in a more inclusive use of statistical approaches rather than a single method for mean separation. One of the major changes made was to modify the Instructions to Authors to accept all appropriate statistical methods for agronomic studies. This change increased the papers that addressed spatial aspects in field studies. One of the goals of this change was to foster more research papers describing innovative approaches for research and field-scale studies.

\section{| 996-200 |}

In 1996, 6 yr before the advent of Manuscript Tracker, ${ }^{1}$ we initiated electronic manuscript submission and review. Technical Editor Robert Lascano conducted the trial run and found that it took 1 to $5 \mathrm{~d}$ to identify reviewers and forward the electronic files, $55 \mathrm{~d}$ before the first review comments were electronically returned to the authors, and $87 \mathrm{~d}$ for the authors to electronically submit their revision. This initial electronic manuscript was accepted. We formally initiated electronic submissions in 1998 (ASA, 1998b); we received eight such submissions that year.

The membership requirement for publication was dropped in 1997. For 1998, we added the Forum section to allow authors to address a thought-provoking concept or idea to generate discussion among our readership. We also changed the Notes section to Notes and Unique Phenomena so that authors could present results for unusual occurrences such as crop response or other observations following hail damage (ASA, 1998b).

Several changes were implemented in 1999 through 2001. At the 1999 annual meetings in Salt Lake City, UT, the Editorial Board voted to start recognizing excellent reviewers (ASA, 2000; Barbarick, 2000). The award was titled the Editors' Citation for Excellence in Manuscript Review to recognize outstanding reviewers on an annual basis from various subject areas within the journal. A formal symposium-paper policy was approved at the 2000 Editorial Board meeting in Minneapolis, MN (ASA, 2001). The policy spelled out the procedure for publishing manuscripts in Agronomy Journal that were the result of symposia if they were found to have suitable subject matter (Barbarick, 2001). We debuted a new full-color cover, starting with the 1999 volume year (ASA, 1999). We began accepting production agriculture papers when the Journal of Production Agriculture was slated for termination in 2000 (ASA, 1999, 2000; Barbarick, 2000). With submission and eventual acceptance of production agriculture papers, we highlighted these articles in the table of contents from 2001 through 2006. In 2001, we published our first full color figure (Barbarick, 2001). Agronomy Journal was first posted online by Springer-Verlag with Volume 90 (1998) and then in 2000 with HighWire Press, Palo Alto, CA. ${ }^{2}$

\section{2-2007}

On 13 Mar. 2002 we began using Manuscript Tracker for submitting, registering, reviewing, and tracking manuscripts submitted to Agronomy Journal (ASA, 2003). From this date forward all manuscripts submitted to the journal were logged into the Manuscript Tracker system. If manuscripts were submitted as paper copies, the Editor created a record in Manuscript Tracker and paper copies were handled as in previous times. Starting 1 Jan. 2004, the Editorial Board no longer accepted paper submissions (Pearson, 2004). Only electronic files of manuscripts were allowed after that date. At the time, the thought of eliminating the use of paper copies seemed a bit unrealistic; we were so used to dealing with paper. We have now been handling electronic files for several years and this has become very routine and normal. We questioned how readily some authors would adapt to using only electronic files, particularly scientists in developing countries who may not have adequate computer technology. This has not been a significant problem for most authors. They have adapted quite well to the Manuscript Tracker system.

Also during 2002, we initiated the preparation of news releases of selected papers from each issue of Agronomy Journal (Pearson, 2003). We contacted the authors of these selected articles and worked with them to prepare a news release of their paper. News releases were distributed through a distribution service of the American Association of the Advancement of Science to more than 4000 international science media. Articles from Agronomy Journal were also publicized on the web page of the Societies and in CSA News and the News Flash (semimonthly email sent out to members). Promoting the research published in Agronomy Journal continues to evolve and expand with the hope that the impact and contribution of the science found in Agronomy Journal will increase (ASA, 2005, 2006).

More formal Associate Editor appointments were instituted during 2002. This included a letter of appointment and certificate of appointment, both signed by the Editor. The certificates of appointment were suitable for framing and it was hoped that new Associate Editors would display them.

The use of electronic media continued to be more encompassing for publishing Agronomy Journal. On January 2003, PDF galley proofs (e-proofs) were sent to authors via the Internet (ASA, 2003). With the use of the Internet and Manuscript Tracker for submitting, registering, assigning, and tracking manuscript and the use of PDF galley proofs, a sizeable savings in postage costs has been realized.

\footnotetext{
I Manuscript Tracker is an online, wed-based system for electronically submitting and reviewing manuscripts. Manuscript Tracker is used by authors, reviewers, and editors.

2 HighWire Press (http://highwire.stanford.edu/), a division of the Stanford University Libraries, hosts more than 1000 scientific journals. Agronomy Journal is available at http://agron.scijournals.org/.
} 


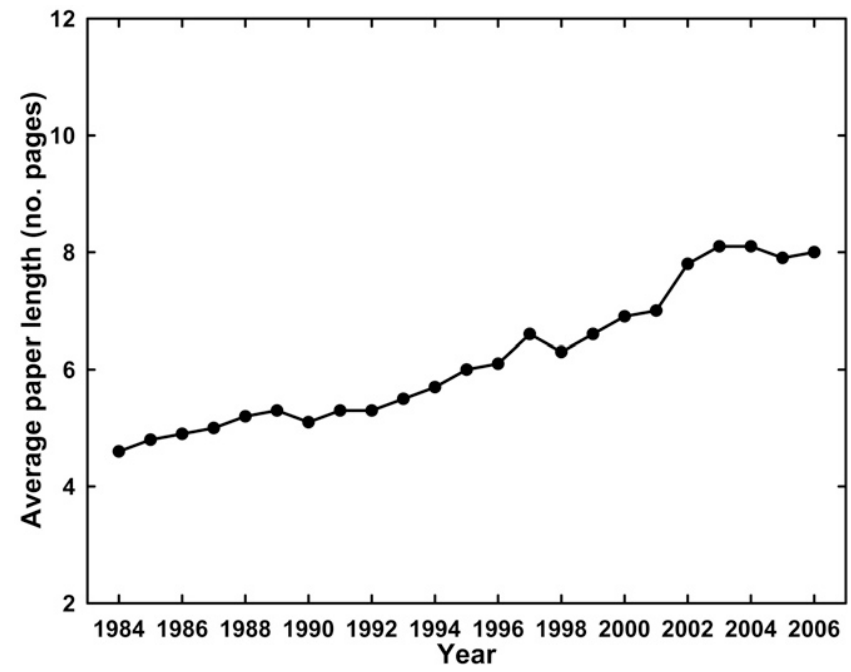

Fig. 6. The average length of articles published in Agronomy Journal from 1984 through 2006.

Table 2. International papers submitted and international papers published in Agronomy Journal in recent years.

\begin{tabular}{ccc}
\hline $\begin{array}{c}\text { Volume } \\
\text { year }\end{array}$ & $\begin{array}{c}\text { International papers } \\
\text { submitted } \dagger\end{array}$ & $\begin{array}{c}\text { International papers } \\
\text { published } \ddagger\end{array}$ \\
\hline & & $\%$ \\
2000 & - & 31 \\
2001 & - & 34 \\
2002 & 36 & 23 \\
2003 & 30 & 24 \\
2004 & 28 & 22 \\
2005 & 38 & 23 \\
2006 & 39 & 26 \\
\hline
\end{tabular}

$\dagger$ Percentage of the total number of manuscripts submitted that was international. $\ddagger$ Percentage of the total number of manuscripts published that was international.

Beginning in 2004, the traditional page charges were replaced with a publication fee. Some of the history of how page charges were assessed can be found in ASA (1979b, 1981, 1998a). The publication fee was on a per-manuscript basis, (ASA, 2004a, 2004b; Pearson, 2005).

With the March-April 2004 issue of Agronomy Journal, authors began to select their own table of contents headings. As is the practice today, the authors are provided a list of headings and they choose the heading from the list that best describes the content of their manuscript. The procedure gives authors increased input into the publishing of their articles (Pearson, 2004).

After much work, largely through the efforts of Charles Roth from Purdue University, a seven-CD set of the back issues (Vol. 1-93, 1908-2001) of Agronomy Journal became available for purchase during 2004 (Pearson, 2005). Digitizing the journal was part of a larger effort to make CD sets for all Society journals. The seven-CD set for Agronomy Journal also included the Journal of Production Agriculture and the Journal of Natural Resource and Life Sciences Education (ASA, 2004b). Thus, all volumes of Agronomy Journal are now available in a digital medium.

Starting with the May-June 2005 issue, we began using a concept known as "continuous publication" (ASA, 2005, 2006; Pearson, 2005, 2006). Manuscripts are posted online each month with fully citable reference information. Continuous publication is an economical method for faster publishing of research papers, rather than waiting 2 mo before a paper issue of Agronomy Journal is received in the mail.

During the meetings in Salt Lake City in November 2005 the Editorial Board approved the addition of an Acquisitions Associate Editor (ASA, 2006; Pearson, 2006). Wesley Rosenthal from Texas A\&M University at the Blackland Research Center was appointed on 22 Feb. 2006 as our first Acquisitions Associate Editor. The Acquisitions Associate Editor is responsible, in cooperation with the Editor and the Editorial Board, for soliciting content for Agronomy Journal, with a primary focus on obtaining review articles.

During the past $23 \mathrm{yr}$, the length of articles published in the journal increased from an average of 4.6 pages in 1984 to 8.4 pages in 2006 (Fig. 6). Fuccillo (1983) noted that the average length of articles in Volume 50 (1957) was 3.7 pages. Thus, during the past $50 \mathrm{yr}$ (from 1957 to 2006) the average length of articles has more than doubled and over the past $23 \mathrm{yr}$ (from 1984 to 2006), the average article length has increased 83\%. Pages charges for Agronomy Journal and most of the other society journals underwent considerable change in 1979 (ASA, 1979a, 1979b) and again in 1981 (ASA, 1981). In 1979, page charges were $\$ 30$ per page for 4 journal pages or less. For articles over 4 pages, a $\$ 120$ production charge was levied for each page and assessed in half page increments. In 1981, page charges were increased to $\$ 40$ per page for 4 journal pages or less. For articles over 4 pages, the production charge was increased to $\$ 150$ a page. It was part of the editorial culture to encourage papers to be short with the idea that they would be more readable. This was somewhat of a deterrent against long articles and encouraged authors to prepare concise papers during this time period. In 1998, a new page charge structure went into effect and there were no charges for the first 6 printed pages with a production charge of $\$ 165$ per printed page beyond 6 pages of a manuscript (ASA, 1998a).

The overall reason for an increase in paper length is not certain, but we speculate that the additional length of many articles may be the result of scientists addressing more complex issues and the capability of collecting more data with today's instrumentation, thus more verbiage is needed to explain how the study was conceived, conducted, and to present and interpret the findings and impacts of those findings of these more complex and comprehensive research projects. We doubt that authors of today are any more or any less verbose than authors of earlier times. Another possible reason for longer papers is the publication fee. Authors have no financial deterrent when they write long papers. It is interesting to note that concern about the length of articles is not new. Editor M.R. Haag was concerned about a backlog of manuscripts that had developed during the early 1950s and he wrote in his annual report (ASA, 1951), "One of the steps toward dealing with the matter is insistence on shorter and more concise papers."

Data for international papers submitted and published in Agronomy Journal have only been collected in recent years (Table 2). International papers are valued in the journal and are needed for the contribution they make to the agronomic and natural resource sciences and to the viability of our publication. As an Editorial Board we continue to encourage the submission of high quality international 


\begin{tabular}{|c|c|c|}
\hline Year & Volume & Significant change by year \\
\hline 1983 & 75 & 75th Anniversary Year (ASA, 1983b) \\
\hline 1984 & 76 & Changed heading from "Literature Cited" to "References" (ASA, 1984b) \\
\hline 1985 & 77 & Changes begin for manuscripts to be submitted directly to Editor and not Headquarters (ASA, 1985) \\
\hline 1986 & 78 & First personal computer purchased for use by the Headquarters Editorial Staff (ASA, 1986) \\
\hline 1987 & 79 & First two software papers submitted to the journal (ASA, 1987) \\
\hline 1988 & 80 & The possibility of submitting manuscripts electronically discussed (ASA, 1988) \\
\hline 1989 & 81 & $\begin{array}{l}\text { Time allowed for author revisions of papers shortened from } 6 \text { to } 3 \text { mo (ASA, 1989b). Beginning in 1989, other society } \\
\text { journals can be substituted for Agronomy Journal to satisfy the ASA membership journal requirement (ASA, 1989a) }\end{array}$ \\
\hline 1990 & 82 & New divisions for the table of contents debuts with the first issue of 1990 (ASA, 1990) \\
\hline 1991 & 83 & The words "An International Journal" added to the cover starting with the Jan-Feb 1991 issue (ASA, I99I) \\
\hline 1992 & 84 & Double-blind reviews approved for a 2-yr trial (ASA, 1992) \\
\hline 1993 & 85 & Discussed perception that the journal is too conservative and thus loses valuable submissions (ASA, 1993) \\
\hline 1994 & 86 & Sheridan Press begins printing Agronomy Journal and the other five Society journals (ASA, 1994) \\
\hline 1995 & 87 & All journal manuscripts are now edited using a computer (ASA, 1995) \\
\hline 1996 & 88 & Initiated electronic manuscript submissions \\
\hline 1997 & 89 & Dropped membership requirement for publication (ASA, 1998b) \\
\hline 1998 & 90 & $\begin{array}{l}\text { Forum section initiated; initiated "fast-track" manuscript reviews; changed the "Notes section } \\
\text { to "Notes and Unique Phenomena" (ASA, 1998b); Online with Springer-Verlag }\end{array}$ \\
\hline 1999 & 91 & $\begin{array}{l}\text { New Agronomy Journal color cover debuts along with new headings in the Table of Contents (ASA, 1999); The words “... } \\
\text { of Agriculture and Natural Resource Sciences" added to the cover starting with the Jan-Feb I999 issue (ASA, 1999). Began } \\
\text { accepting "Production Agriculture" manuscripts coinciding with the termination of the Journal of Production Agriculture }\end{array}$ \\
\hline 2000 & 92 & Began highlighting "Production Papers" in the table of contents; first color figure published \\
\hline 2001 & 93 & Online with HighWire Press, Palo Alto, CA \\
\hline 2002 & 94 & Began using Manuscript Tracker for online manuscript submissions (ASA, 2003) \\
\hline 2003 & 95 & An author/subject index is no longer published [Agron. J. 95(6):iii] \\
\hline 2004 & 96 & $\begin{array}{l}\text { Paper manuscripts are no longer accepted; began using publication fees instead of page charges; largest } \\
\text { volume ever published (1828 pages); CD back-issue set available (Pearson, 2004; ASA, 2003) }\end{array}$ \\
\hline 2005 & 97 & Continuous publication begins with the May-June 2005 issue (ASA, 2005) \\
\hline 2006 & 98 & $\begin{array}{l}\text { An Acquisitions Associate Editor is added to the Editorial Board; May-June } 2006 \text { is } \\
\text { the largest issue ever published at a hefty } 456 \text { pages (ASA, 2005) }\end{array}$ \\
\hline 2007 & 99 & Publication fees and page charges undergo extensive review; "Production Papers" highlighting discontinued \\
\hline
\end{tabular}

papers and we seek to help international authors and others to prepare manuscripts that are suitable for publication in Agronomy Journal.

Some of the major changes that Agronomy Journal has experienced over the past $25 \mathrm{yr}$ are summarized in Table 3. As a current snapshot of Agronomy Journal, we published $60 \%$ of the manuscripts submitted in 2005. In both 2003 and 2004 , we accepted $55 \%$ of the manuscripts submitted.

Recently, the use of metrics to compare peer journals has become more widely used. In a comparison of 48 peer journals in 2005, the impact factor of Agronomy Journal ranked 12 th at 1.473 and the total citations for the journal ranked fourth at 6723 (Thompson Institute for Scientific Information, 2006).

\section{WHERE DOWE GO FROM HERE?}

Our biggest challenge may be to stay economically viable in the face of increasing pressure to allow full and free public access to articles. We also need to enhance Agronomy Journal as the preeminent source of agronomic information. Our journal is well-suited for the integrative, multidisciplinary research that granting agencies highly value today. We encourage and are attempting to work actively with our international colleagues and others to help them prepare high-quality submissions of their research results. Too often, good science is not recognized because the writing is substandard.
Of continuing importance will be for us to be faster at completing reviews, revisions, and publishing articles in Agronomy Journal. We also need to think globally and inclusive in all related aspects of our scientific publishing.

Agronomy Journal also is important as a record of the business, functions, and accomplishments of the American Society of Agronomy and its members. This will continue to be important in the future as it has been in the past.

We would be well served as an Editorial Board to function in a more customer-oriented approach. This does not mean we put less emphasis on our scientific values, but in performing our editorial duties we are, in fact, performing service to our customers (the authors, subscribers, and readers) and we should perform all those duties and services in the best possible manner.

The journal will not survive and thrive without qualified reviewers and editors. People should seek to acquire skill sets for reviewing and editing and then volunteer to be reviewers and editors. As Laude et al. (1962) and Gary A. Peterson (ASA, 1997) have both noted that our journals are key to our societies. Thus, our publications are critical to the continuation of our societies.

Agronomy Journal is now $100 \mathrm{yr}$ old. Its success, its longevity, its scientific value — can be attributed to the dedication of many people who have contributed as authors, reviewers, editors, and others. We are honored to have played a small part in the 100-yr history of Agronomy Journal. Other 
authors, reviewers, and editors will follow us. We fully expect the future of Agronomy Journal will be even more exciting, rewarding, challenging, and valued as the past $100 \mathrm{yr}$. We eagerly look forward to the next $100 \mathrm{yr}$ of Agronomy Journal.

\section{REFERENCES}

ASA. 1948a. Maurice R. Haag named Agronomy Journal Editor. J. Am. Soc. Agron. 40:1142-1143.

ASA. 1948b. Agronomic affairs. J. Am. Soc. Agron. 40:1148-1154.

ASA. 1951. The forty-third annual meeting of the American Society of Agronomy. Agron. J. 43:626-628.

ASA. 1952. Agronomic affairs. Agron. J. 44:390-393.

ASA. 1953. Agronomic affairs. Agron. J. 45:221-224.

ASA. 1979a. Executive Vice-President's report. Agron. J. 71:188-192.

ASA. 1979b. Reports of divisions, branches, and committees. Agron. J. 71:193-214.

ASA. 1981. ASA Executive Committee meetings. Agron. J. 73:202-214.

ASA. 1982. Reports of divisions, branches, and committees. Agron. J. 74:238-251.

ASA. 1983a. Reports of divisions, branches, and committees. Agron. J. 75:375-391.

ASA. 1983b. Diamond jubilee of the American Society of Agronomy. Agron. J. 75:397-400.

ASA. 1984a. ASA Executive committee meetings. Agron. J. 76:324-331.

ASA. 1984b. Reports of divisions, branches, and committees. Agron. J. 76:335-346.

ASA. 1985. Reports of divisions, branches, and committees. Agron. J. 77:334-346.

ASA. 1986. Reports of divisions, branches, and committees. Agron. J. 78:391-401.

ASA. 1987. Reports of divisions, branches, and committees. Agron. J. 79:399-410.

ASA. 1988. Reports of divisions, branches, and committees. Agron. J. 80:361-373.

ASA. 1989a. ASA Headquarters report, 1988. Agron. J. 81:322-324.

ASA. 1989b. Reports of divisions, branches, and committees. Agron. J. 81:335-344.

ASA. 1990. Reports of divisions, branches, and committees. Agron. J. 82:376-384

ASA. 1991. Reports of divisions, branches, and committees. Agron. J. 83:443-453.

ASA. 1992. Reports of divisions, branches and committees. Agron. J. 84:281-291.

ASA. 1993. Reports of divisions, branches and committees. Agron. J. 85:443-453.

ASA. 1994. Reports of divisions and committees, 1993. Agron. J. 86:377392.

ASA. 1995. Reports of ASA divisions, branches, and committees. Agron. J. $87: 294-308$
ASA. 1997. Reports of ASA divisions, branches, and committees. Agron. J. 89:302-316.

ASA. 1998a. ASA Headquarters report, 1997. Agron. J. 90:242-255.

ASA. 1998b. Reports of ASA divisions, branches, and committees. Agron. J. 90:256-270.

ASA. 1999. Reports of ASA divisions, branches, and committees 1998. Agron. J. 91:504-521.

ASA. 2000. Reports of ASA divisions, branches, and committees, 1999. Agron. J. 92:560-575.

ASA. 2001. Reports of ASA divisions, branches, and committees, 2000. Agron. J. 93:687-707.

ASA. 2003. Reports of ASA divisions, branches, and committees, 2002. Agron. J. 95:734-761.

ASA. 2004a. ASA Headquarters report, 2003. Agron. J. 96:857-872.

ASA. 2004b. Reports of ASA divisions, branches, and committees, 2003. Agron. J. 96:873-893.

ASA. 2005. Reports of ASA divisions, branches, and committees, 2004. Agron. J. 97:998-1011.

ASA. 2006. Reports of ASA divisions, branches, and committees, 2005. Agron. J. 98:840-848.

Ball, C.R., H.L. Shantz, and C.F. Shaw. 1928. Median terms in adjectives of comparison. J. Am. Soc. Agron. 20:182-191.

Barbarick, K.A. 2000. Letter from the Editor. Agron. J. 92:189.

Barbarick, K.A. 2001. Letter from the Editor. Agron. J. 93:261.

Fuccillo, D.A. 1983. The 75th publication year of Agronomy Journal. Agron. J. 75:413-417.

Laude, H.H., M.F. Miller, J.D. Luckett, G.G. Pohlman, D.S. Metcalfe, W.H. Pierre, and E. Truog. 1962. History of American Society of Agronomy: First fifty years - 1907 to 1957. Agron. J. 54:57-69.

Luckett, J.D. 1927. Methods of graphic representation of experimental data. J. Am. Soc. Agron. 19:27-40.

Lyon, T.L. 1933. History of the organization of the American Society of Agronomy. Agron. J. 25:1-9.

Pearson, C.H. 2003. Letter from the Editor. Agron. J. 95:231-232.

Pearson, C.H. 2004. Letter from the Editor. Agron. J. 96:319-320.

Pearson, C.H. 2005. Letter from the Editor. Agron. J. 97:343-344.

Pearson, C.H. 2006. Letter from the Editor. Agron. J. 98:229-230.

Smith, D.C. 1980. Development of the American Society of Agronomy, 1958-1977. Agron. J. 72:227-240.

Thatcher, R.W. 1927. Should the results of agronomic research be published in bulletins, or in scientific journals, or both? J. Am. Soc. Agron. 19:2-7.

Thompson Institute for Scientific Information. 2006. ISI web of knowledge. v. 3.0. Available at http://portal.isiknowledge.com/portal.cgi?DestApp =JCR\&Func=Frame [verified 25 May 2007]. Thompson Institute for Scientific Information, Stamfort, CT.

Throckmorton, R.I. 1941. History of the American Society of Agronomy. J. Am. Soc. Agron. 33:1135-1140.

Warburton, C.W. 1925. Taking agronomic research to the farmer. J. Am. Soc. Agron. 17:757-764. 